\title{
The 13 August 2010 catastrophic debris flows after the 2008 Wenchuan earthquake, China
}

\author{
Q. Xu ${ }^{1}$, S. Zhang ${ }^{2}$, W. L. Li ${ }^{1}$, and Th. W. J. van Asch \\ ${ }^{1}$ State key Laboratory of Geohazard Prevention and Geoenvironment Protection, Chengdu University of Technology, \\ Chengdu, 610059, China \\ ${ }^{2}$ Dept. of Civil and Environment Engineering, The Hong Kong University of Science and Technology, Hong Kong, China \\ ${ }^{3}$ Dept. of Physical Geography, Utrecht University, P.O. Box 80115, 3508 TC, Utrecht, The Netherlands
}

Correspondence to: Q. Xu (xuqiang_68@126.com)

Received: 6 August 2011 - Revised: 8 December 2011 - Accepted: 10 December 2011 - Published: 19 January 2012

\begin{abstract}
From 12 to 14 August 2010, heavy rainstorms occurred in the Sichuan province in SW China in areas which were affected by the 2008 Wenchuan Earthquake, inducing catastrophic debris flows. This disaster is named as "the 8.13 debris flows". The results of the research presented in this paper show that the 8.13 debris flows are characterized by a simultaneous occurrence, rapid-onsets, destructive impacts, and disaster chain effects. They are located along the seismic fault, because the source materials mainly originate from loose deposits of landslides which were triggered by the Wenchuan Earthquake. The presence of large amounts of these loose materials on the slopes and the development of high intensity rainfall events are the main causes for the formation of these debris flows. The study of the 8.13 debris flows can provide a benchmark for the analysis of the long-term evolution of these debris flows in order to make proper engineering decisions. A flexible drainage system is proposed in this paper as a preventive measure to mitigate the increasing activity of these debris flows in the earthquakeaffected area.
\end{abstract}

\section{Introduction}

A debris flow is defined as a poorly sorted mixture of soil, rock, vegetation and water that rapidly flows down a slope as a response to gravity (Varnes, 1978; Iverson, 1997). It can be very destructive, causing loss of human lives, destruction of houses and facilities, and damage to the environment. The 2008 Wenchuan Earthquake in China triggered over 45000 landslides. The loose soil and rock materials of these landslides are distributed on steep slopes and in channels. Under normal weather conditions, such deposits are at a quasi stable state. However in the wet season, these materials can easily evolve into debris flows once triggered by heavy rainfall.

On 13 August 2010, heavy rainstorms occurred in a part of the area affected by the 2008 Wenchuan Earthquake. A total of three catastrophic debris flows occurred: the Wenjia gully and Zoumaling gully debris flows near the Town of Qingping; the Hongchun gully debris flow near the town of Yingxiu and the Longchi debris flow near Dujiangyan City (Fig. 1).

Much research on these rainfall-induced debris flows has been carried out after the earthquake; Xie et al. (2009) predicted an increase in debris flow hazards. The triggering rainfall threshold for debris flows significantly decreased after the Chi-Chi Earthquake in Taiwan (Shieh et al., 2009). Tang and Liang (2008) came to a similar conclusion after conducting field investigation and statistic analyses of debris flows that occurred in the Beichuan County on 24 September 2008. The understanding of the various hydrological triggering mechanisms of these complex debris flows is a prerequisite for the assessment of hazard, the development of alarm thresholds, and for risk management (Berti and Simoni, 2003).

Debris flows in temperate environments are mostly generated by landslide failures (Campbell, 1975; Iverson et al., 1997), while debris flows in alpine regions are generally induced by the erosion and entrainment of hill-slope and channel material by surface runoff after intense rainfall (e.g. Fryxell and Horgerg, 1943; Berti et al., 1999; Gregoretti and Fontana, 2008). Several authors give different hydro mechanical explanations for the transformation of sliding material into debris flows. Sassa et al. (1980) pointed 


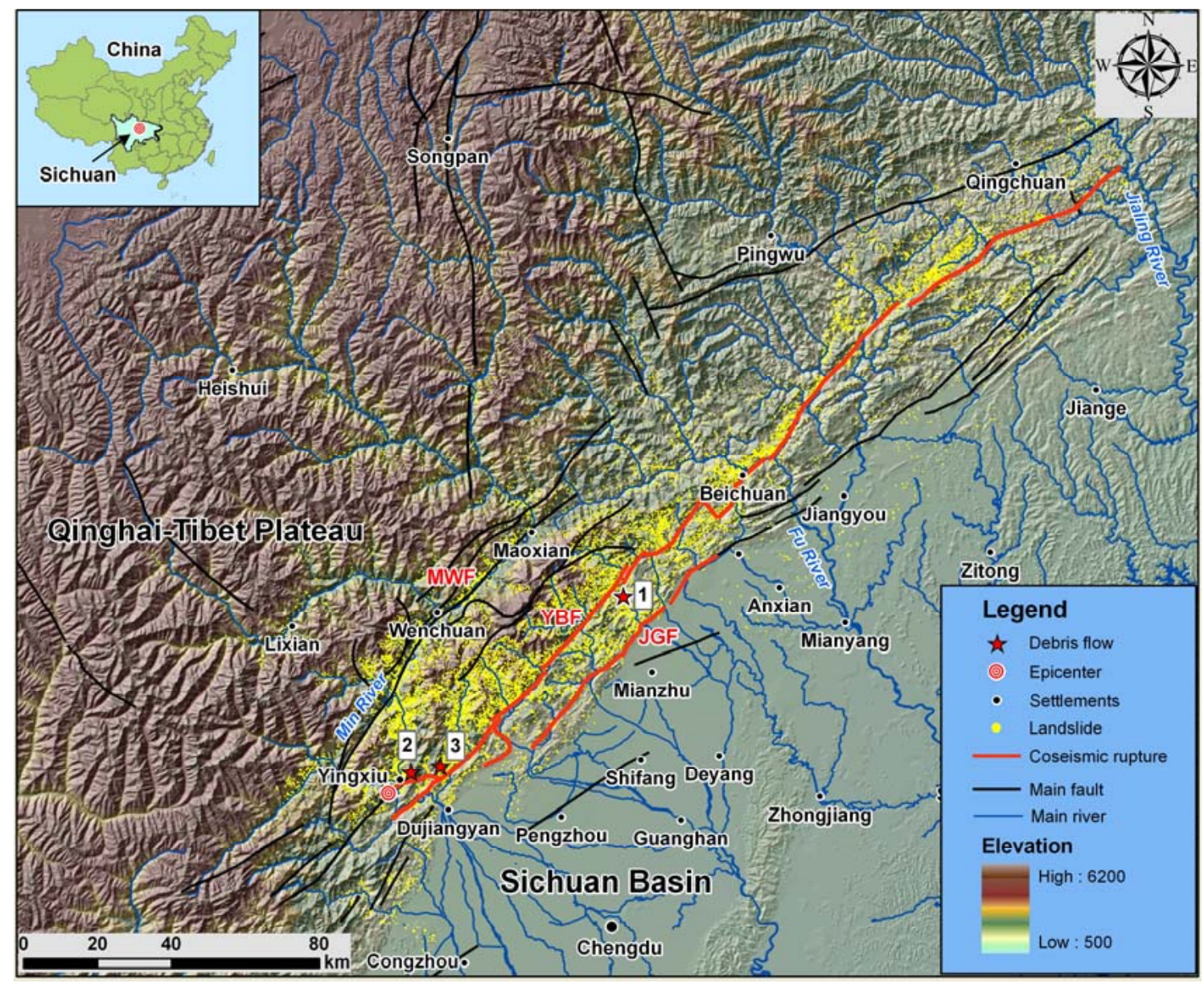

Fig. 1. Distribution map of landslides triggered by the Wenchuan Earthquake and three catastrophic debris flows triggered by the rainstorms on 13 August 2010 (MWF: Maoxian-Wenchuan Fault; YBF: Yingxiu-Beichuan Fault; JGF: Jiangyou-Guanxian Fault. 1: Wenjia gully and Zoumaling gully debris flows near Qingping Town; 2: Hongchun gully debris flow; 3: Longchi debris flow). The landslide distribution map was derived from a rapid landslide inventory made by Huang and Li (2009).

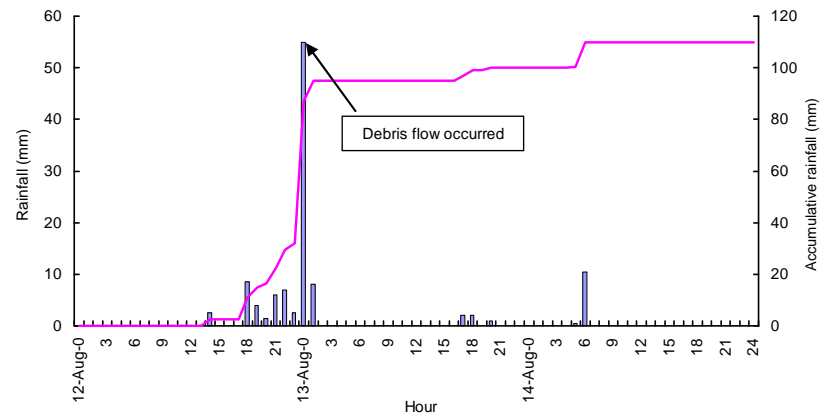

Fig. 2. Distribution of hourly and cumulative precipitation between 12 and 14 August 2010 in Qingping Town. out that during the movement of a landslide the overburden pressure on the in-situ soil could generate a liquefied layer. Ashida et al. (1983) explained the initiation process from a deformation energy point of view. Iverson et al. (1997) suggested three processes for the formation of a landslide induced debris flow: widespread Coulomb failure, partial or complete liquefaction by high pore fluid pressure induced by compaction during failure, and conversion of landslide translational energy into internal vibrational energy within the sliding mass. Johnson and Rodine (1984) held that poor sorting of particles within the mobilized sliding mass was a cause of the debris flow formation. Tani (1968) and Takahashi (1991) mentioned the collapse of landslide dams as an important cause for debris flow initiation. In this paper, the concentration run-off erosion of the loose deposits distributed on hill-slopes and along channels are considered as the main source for the 8.13 debris flows. 


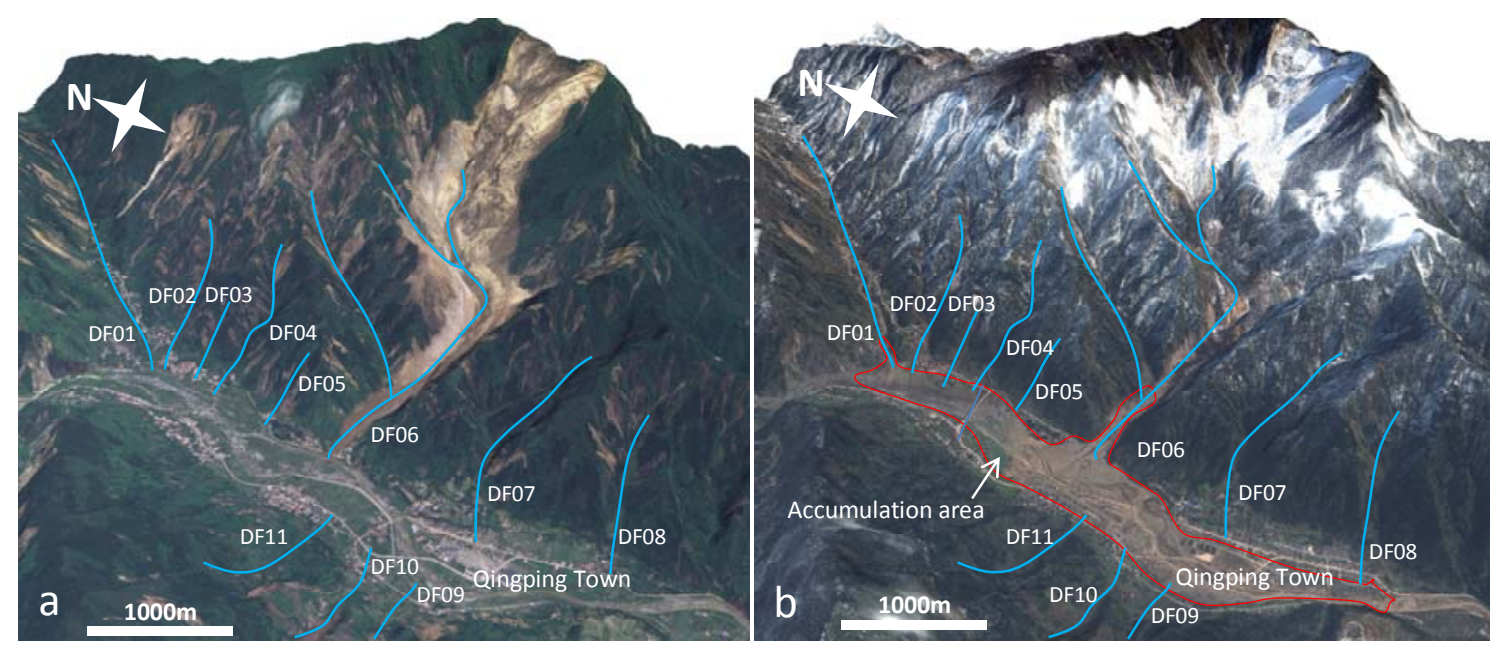

Fig. 3. Pre-seismic and post-seismic aerial photographs of the 13 August 2010 debris flow events near to Qingping Town (a: taken on 18 May 2008; b: taken on 13 December 2010), DF is the abbreviations of Debris Flow gulley.

The main purpose of this study is the description and analysis of the characteristics and triggering mechanism of the three selected debris flow events, which were mentioned above. First, the triggering mechanism by intensive rainfall is analyzed. Secondly, the characteristic of the 8.13 debris flows is summarized. Finally, we will show how the new findings about debris flow prevention can support future studies and may serve as a focus reference for the government to improve the protection of people and to mitigate such hazards.

\section{General settings}

The study area is situated in the transitional mountainous belt characterized by rugged mountains and deep valleys (i.e. 2008 Wenchuan Earthquake zone). As shown in Fig. 1, the NE-SW Longmenshan fault zone is formed as an intercontinental transfer fault, which is composed of three subparallel thrust faults, including the Maoxian-Wenchaun fault, the Yingxiu-Beichuan fault, and the Jiangyou-Guanxian fault. Due to the extrusion of the Qinghai-Tibet Plateau and the Sichuan Basin, the Longmenshan fault region has always been active until recently with consequently a high frequency of strong earthquakes. The Wenchuan Earthquake crushed the Yingxiu-Beichuan fault (about $240 \mathrm{~km}$ length).

The study area is underlain by Granitic rocks, Sinian pyroclastic rocks, Carboniferous limestones, and Triassic sandstones. Loose Quaternary deposits are distributed in the form of terraces and alluvial fans. The Min River and Fu River are the most important rivers in this region formed by both the tributaries of the Yangtze River (Fig. 1). The study area belongs to the subtropical monsoon climate zone characterized by high precipitation. The annual average rainfall over a period of $30 \mathrm{yr}$ is $800-1600 \mathrm{~mm}$ which is concentrated in a rainy season from June to September.

\section{Processes and effects of the 8.13 debris flows}

In this section, the processes, characteristics and effects of the 8.13 debris flows are reported. This section first describes the Wenjia gully and Zoumaling gully debris flows, which are located near Qingping Town, followed by an analysis of the Hongchun gully and Longchi debris flows. Data used in this section have been gathered through the study of aerial photographs and topographic maps, as well as through field investigation.

\subsection{The Wenjia gully and Zoumaling gully debris flows near Qingping Town}

Qingping town is located near Deyang City, in the northwestern part of Sichuan Province (Fig. 1). It covers an area of $2.9 \times 10^{6} \mathrm{~m}^{2}$ and accommodates approximately 4000 people. From 12 to 14 August 2010, a storm swept over the study area. The monitoring results of precipitation in Qingping Town station (Fig. 2 and Fig. 3a) show that the rainfall event in Qingping Town started at about 14:00 on 12 August and ended at about 01:00 on 13 August. According to the records, the cumulative rainfall was $95 \mathrm{~mm}$ within a period of $12 \mathrm{~h}$, and the maxium hourly precipitation was $55 \mathrm{~mm}$ at 00:00 on 13 August. However, according to the description of a resident witness in Qingping Town, this rainfall event was local heavy rainfall, for the precipitation in the middle and upper parts of east mountains (DF02-DF06 gully source zone as shown in Fig. 3a) in Qingping Town was far more than that of Qingping Town itself. The analysis of local Bureau of Meteorology suggested that the daily cumulative rainfall in the middle and upper segments of Wenjia gully should exceed $200 \mathrm{~mm}$ and the highest hourly rainfall should be about $70 \mathrm{~mm}$, but the observed precipitation by Qingping Town station was much lower than that. 
Table 1. Basic data for 11 debris flow gullies around Qingping.

\begin{tabular}{|c|c|c|c|c|c|c|c|c|}
\hline $\begin{array}{l}\text { Gully } \\
\text { code }\end{array}$ & Name & $\begin{array}{l}\text { Catchment } \\
\text { area }\left(\mathrm{km}^{2}\right)\end{array}$ & $\begin{array}{l}\text { Channel } \\
\text { length }(\mathrm{km})\end{array}$ & $\begin{array}{l}\text { Catchment } \\
\text { relief }(\mathrm{km})\end{array}$ & $\begin{array}{l}\text { Channel } \\
\text { gradient }\left({ }^{\circ}\right)\end{array}$ & $\begin{array}{l}\text { Slope angle of } \\
\text { initiation zones }\left(^{\circ}\right)\end{array}$ & $\begin{array}{l}\text { Debris supply } \\
\text { (coseismic landslide) } \\
\left(10^{4} \mathrm{~m}^{3}\right)\end{array}$ & $\begin{array}{l}\text { Volume of } \\
\text { debris flow event } \\
\text { the } 13 \text { August } 2010 \\
\left(10^{4} \mathrm{~m}^{3}\right)\end{array}$ \\
\hline DF01 & Zoumaling & 5.76 & 3.39 & 1.10 & 18.0 & 21.3 & 432.7 & 82.0 \\
\hline DF02 & Luojia & 1.64 & 2.91 & 1.40 & 25.7 & 28.0 & 130.8 & 16.0 \\
\hline DF03 & Dongzi & 0.12 & 0.64 & 0.38 & 30.7 & 33.1 & 4.4 & 1.2 \\
\hline DF04 & Wawa & 0.51 & 1.43 & 0.70 & 26.1 & 31.4 & 40.2 & 9.8 \\
\hline DF05 & Didong & 0.20 & 0.76 & 0.42 & 28.9 & 35.6 & 3.2 & 0.7 \\
\hline DF06 & Wenjia & 7.65 & 4.33 & 1.50 & 19.1 & 25.2 & 5000.0 & 450.0 \\
\hline DF07 & Linjia & 1.27 & 2.16 & 0.76 & 19.4 & 22.7 & 7.8 & 1.5 \\
\hline DF08 & Taiyang & 0.48 & 1.13 & 0.68 & 31.1 & 39.8 & 8.6 & 2.0 \\
\hline DF09 & Maliuwan & 1.01 & 2.06 & 0.80 & 21.2 & 27.4 & 8.3 & 1.3 \\
\hline DF10 & Pujia & 0.85 & 1.75 & 0.80 & 24.6 & 33.5 & 10.0 & 0.8 \\
\hline DF11 & Caodun & 0.29 & 1.31 & 0.68 & 27.4 & 34.0 & 10.3 & 2.4 \\
\hline Total & - & - & - & - & - & - & 5656.3 & 567.7 \\
\hline
\end{tabular}

Table 2. Typical debris flows developed in the Wenjia gully after the 2008 Wenchuan Earthquake.

\begin{tabular}{|c|c|c|c|c|c|c|c|}
\hline Code & Date & $\begin{array}{l}\text { Rainfall/ } \\
\text { day (mm) }\end{array}$ & $\begin{array}{l}\text { Maximum rainfall/ } \\
\mathrm{h}(\mathrm{mm})\end{array}$ & $\begin{array}{l}\text { Rainfall frequency } \\
\text { P }\end{array}$ & $\begin{array}{l}\text { Debris flow discharge } \\
\left(\times 10^{4} \mathrm{~m}^{3}\right)\end{array}$ & $\begin{array}{l}\text { Accumulation area } \\
\left(\times 10^{4} \mathrm{~m}^{2}\right)\end{array}$ & Consequence \\
\hline 1 & 2008.9 .24 & 88 & & $20 \%$ & 90 & 12.5 & Buried road $10 \mathrm{~m}$ \\
\hline 2 & 2010.7 .31 & 60.2 & 51.7 & $20 \%$ & 30 & Blocked in the gully & $\begin{array}{l}\text { Destroyed the } \\
\text { block project } \\
\text { in gully }\end{array}$ \\
\hline 3 & 2010.8 .13 & $>200$ & 70 & $2 \%$ & 450 & 63.5 & $\begin{array}{l}\text { Buried Qingping } \\
\text { Town, destroyed } \\
379 \text { buildings }\end{array}$ \\
\hline 4 & 2010.8 .19 & 145.9 & & $10 \%$ & 30 & 12 & $\begin{array}{l}\text { Destroyed } 100 \\
\text { buildings }\end{array}$ \\
\hline 5 & 2010.9 .18 & 52.0 & & $20 \%$ & 17.6 & 8.5 & $\begin{array}{l}\text { Destroyed } \\
\text { construction } \\
\text { instruments }\end{array}$ \\
\hline
\end{tabular}

Two debris flows were observed in the Wenjia gully and Zoumaling gully at 23:45 on 12 August. On 13 August at 01:00, a large amount of debris was removed from the Wenjia gully and even reached across the Mianyuan River plane. Finally, a deposit fan was formed which immediately blocked the river. The triggering rainfall amount from the start of the rainfall until the occurrence of the debris flow was $55 \mathrm{~mm}$ and lasted $11 \mathrm{~h}$. Figure 3 shows a total of $11 \mathrm{val}-$ leys in the vicinity of the two largest ones the Wenjia gully (DF06) and Zoumaling gully (DF01) valleys. The site investigations and the interpretation from remote sensing images revealed that a total of 11 debris flows in these 11 valleys were simultaneously triggered. The basic information for the debris flow gully's is listed in Table 1. The deposition materials reached a total volume of $567.7 \times 10^{4} \mathrm{~m}^{3}$. The Wenjia gully debris flow is the largest one with a volume of
$450.0 \times 10^{4} \mathrm{~m}^{3}$ while the Zoumaling gully debris flow has a volume of $82.0 \times 10^{4} \mathrm{~m}^{3}$.

The loose materials distributed in the Wenjia gully were deposited by a mass movement occurring during the Wenchuan Earthquake on 12 May 2008. As shown in Fig. 4, when the earthquake happened, a limestone rock mass with a volume of approximately $5000 \times 10^{4} \mathrm{~m}^{3}$ slid down from an elevation between $1780-2340 \mathrm{~m}$. The huge amount of sliding material transformed into a rock avalanche, moved into a SW direction and entered the so called $1300 \mathrm{~m}$ platform (Fig. 4b). Later it turned into an SEE direction along the downstream part of the gully. The high energy of the rock avalanche was able to entrain the shallow, loose, soil material along its flow path increasing the amount of final displaced and depositing material to a total of more than $7000 \times 10^{4} \mathrm{~m}^{3}$. Figure 5 shows that a part of the massive deposits with a volume of 
Table 3. Basic data for 7 tributary-gullies and the main-gully in the Zoumaling catchment.

\begin{tabular}{|c|c|c|c|c|c|c|c|c|}
\hline \multirow[t]{2}{*}{ Name } & \multirow{2}{*}{$\begin{array}{l}\text { Catchment area } \\
\left(\mathrm{km}^{2}\right)\end{array}$} & \multirow{2}{*}{$\begin{array}{l}\text { Channel length } \\
(\mathrm{km})\end{array}$} & \multirow{2}{*}{$\begin{array}{l}\text { Mean gully } \\
\text { gradient }(\%)\end{array}$} & \multicolumn{5}{|c|}{ Loose deposits volume in gully $\left(\times 10^{4} \mathrm{~m}^{3}\right)$} \\
\hline & & & & $\begin{array}{l}\text { Gully } \\
\text { deposits }\end{array}$ & $\begin{array}{l}\text { Slope loose } \\
\text { deposits }\end{array}$ & $\begin{array}{l}\text { Slope } \\
\text { erosion }\end{array}$ & $\begin{array}{l}\text { Total } \\
\text { amount }\end{array}$ & $\begin{array}{l}\text { Volume of the } 13 \text { August } 2010 \text { debris } \\
\text { flow event }\left(10^{4} \mathrm{~m}^{3}\right)\end{array}$ \\
\hline Zoumaling catchment & 5.7 & 3.5 & 14.5 & 137.84 & 125 & 10 & 272.84 & 35 \\
\hline No. 1 Branch & 0.20 & 0.40 & 22.5 & 3.4 & 3.62 & & 7.02 & 2 \\
\hline No. 2 Branch & 0.27 & 0.56 & 38.1 & 0.64 & 1.2 & & 1.84 & 1.5 \\
\hline No. 3 Branch & 0.14 & 0.58 & 38.3 & 1.1 & & & 1.1 & 3 \\
\hline No. 4 Branch & 0.37 & 0.46 & 48.4 & 1.6 & 2.2 & & 3.8 & 2 \\
\hline No.5 Branch & 0.63 & 0.83 & 27.3 & 27.98 & 45.25 & & 73.23 & 20 \\
\hline No. 6 Branch & 0.66 & 0.99 & 29.2 & 27.14 & 18.6 & 0.9 & 46.64 & 13 \\
\hline No. 7 Branch & 0.52 & 0.95 & 22.7 & 12.19 & 6 & 8 & 26.19 & 7 \\
\hline Total & 8.85 & - & - & 211.89 & 201.87 & 18.9 & 316.5 & 83.5 \\
\hline
\end{tabular}
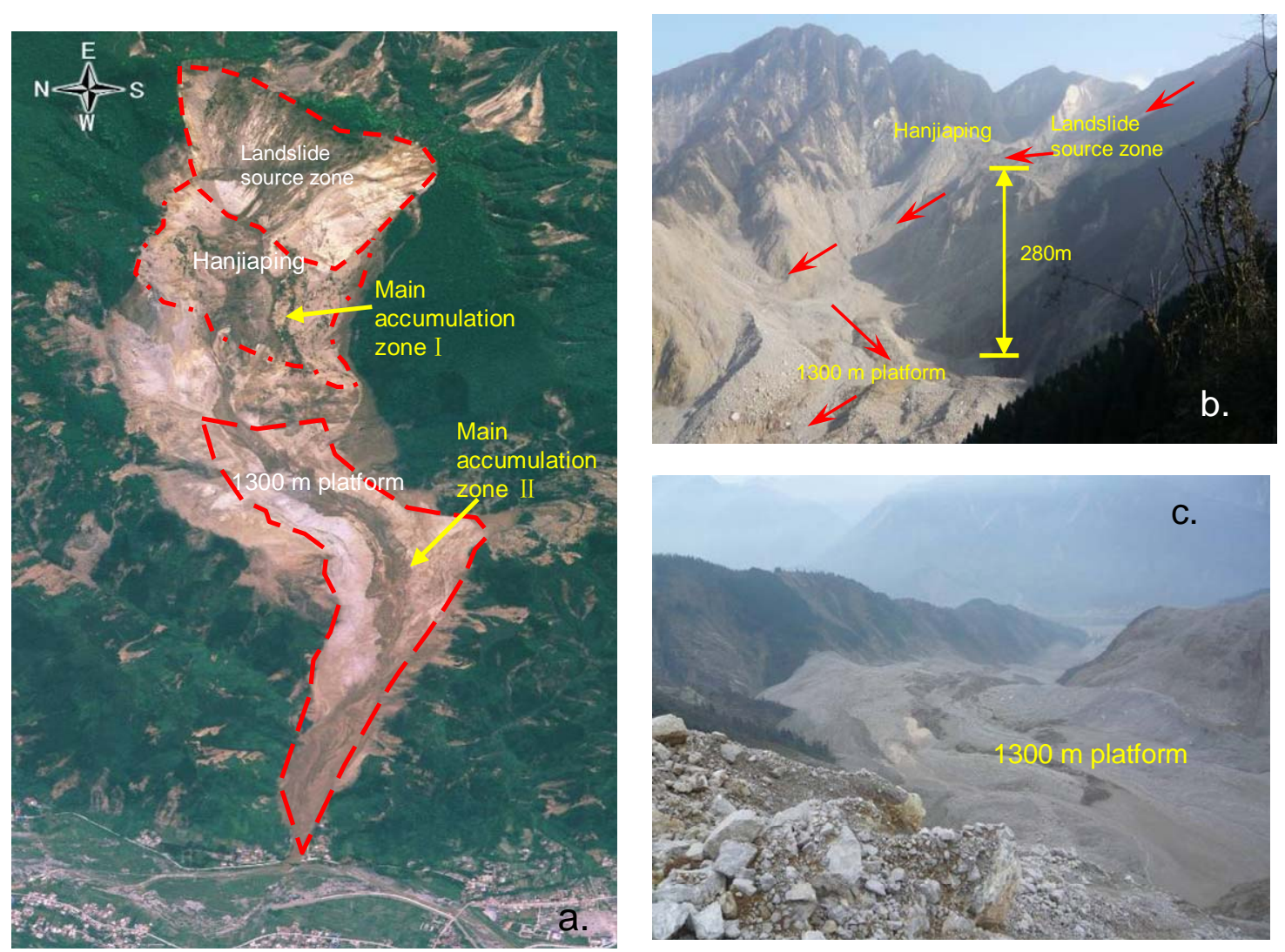

Fig. 4. Wenjia gully landslide induced by the 2008 Wenchuan Earthquake ((a): aerial photograph of Wenjia gully landslide after the Wenchuan earthquake taken on 18 May 2008; (b): Wenjia gully landslide source zone, and $1300 \mathrm{~m}$ platform; (c): $1300 \mathrm{~m}$ platform and loose deposits below it).

$2260 \times 10^{4} \mathrm{~m}^{3}$ accumulated at the toe of the sliding source area on the Hanjia Plain. This loose and coarse material on the Hanjia Plain proved to be very resistant to erosion by overland flow caused by several subsequent rainstorms. Therefore, the finer material deposited in the lower part of the Wenjia catchment near the $1300 \mathrm{~m}$ platform can be considered as the main source for the debris flows. Apart from the huge amount of available material, the gully gradient in this section is rather steep ranging between $32.5 \%$ and $46 \%$. Therefore the loose, relatively fine material could be easily eroded and transformed into debris flows under severe rainstorm conditions. Table 2 lists five debris flow events that happened in Wenjia gully after the earthquake. The most serious one happened on 13 August 2011 with a volume of 


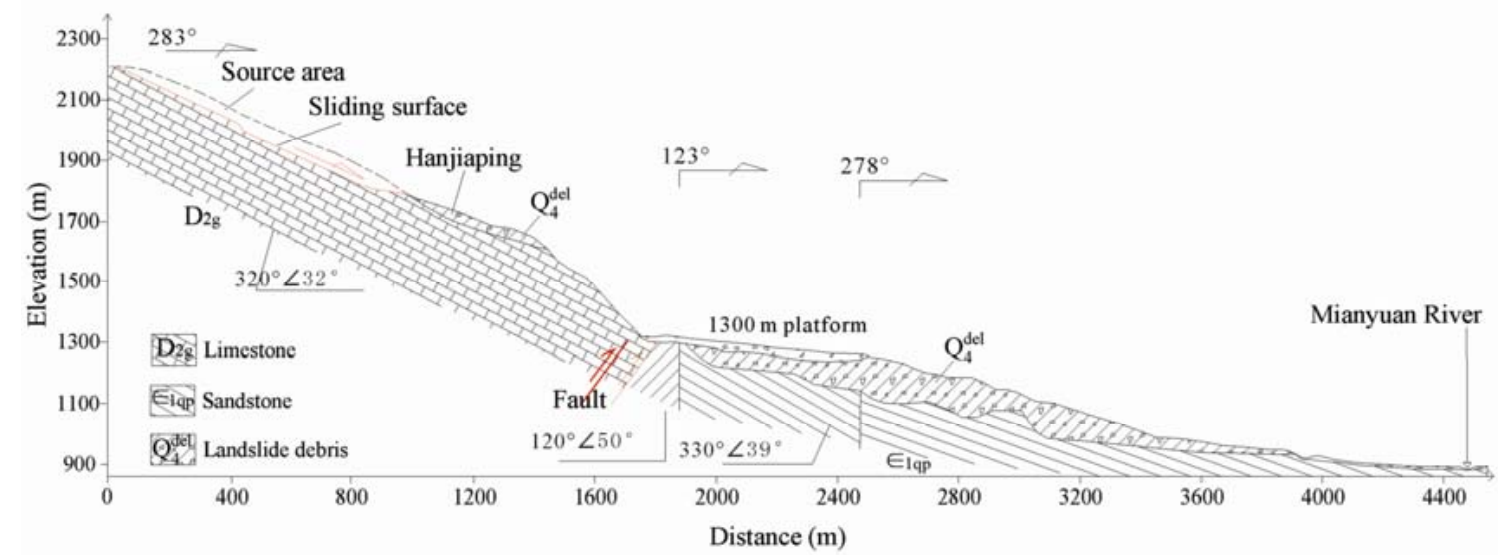

Fig. 5. Section of the Wenjia gully landslide (Huang and Zhao, 2010).
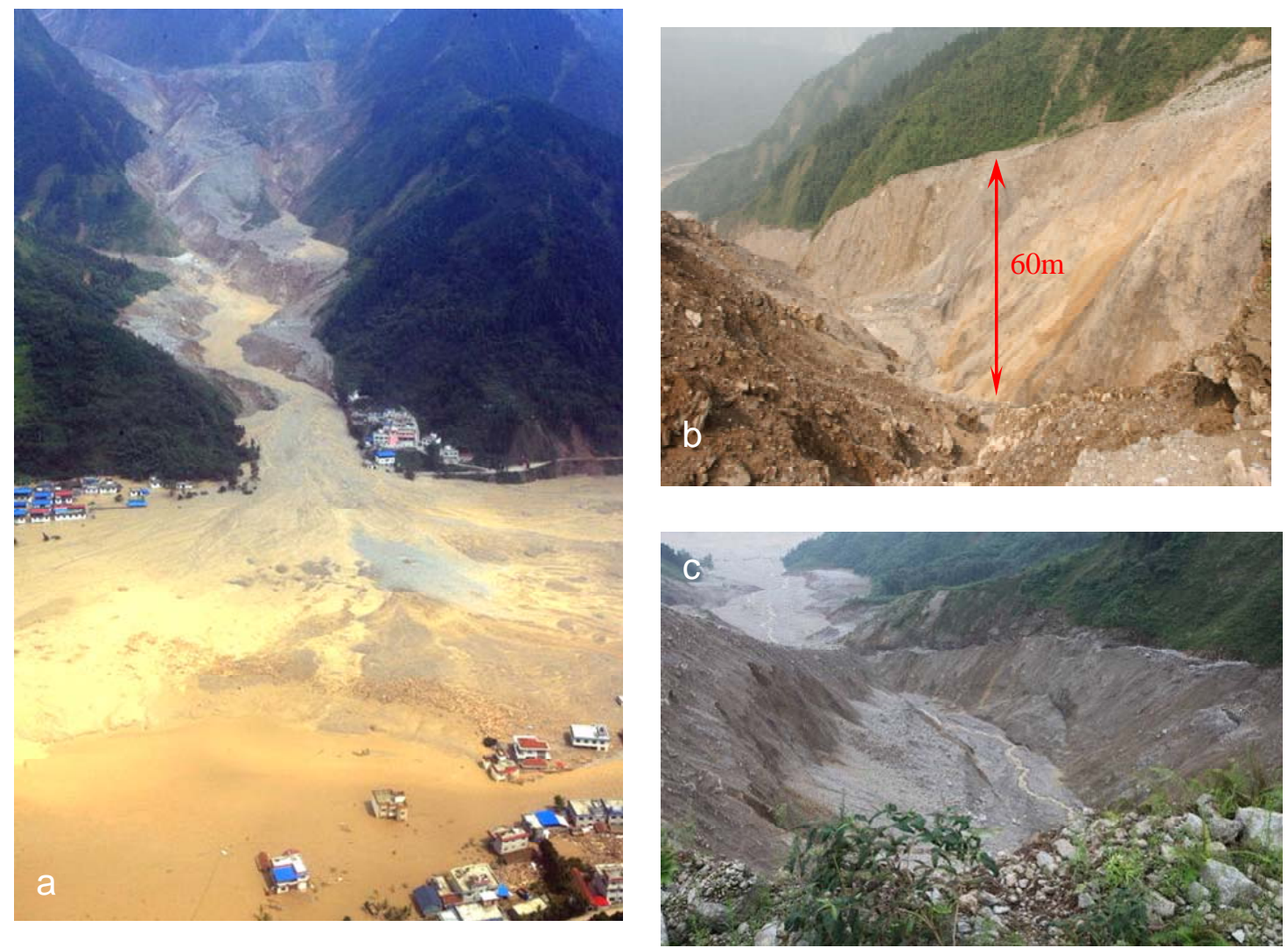

Fig. 6. Photos of the Wenjia gully 8.13 debris flow ((a): overview; (b): channel erosion in the Wenjia gully; (c): local widening by slope failures along the Wenjia gully).

$450 \times 10^{4} \mathrm{~m}^{3}$ and an area extension of $63.5 \times 10^{4} \mathrm{~m}^{2}$. The heavy rainfall in the gully generated a huge amount of surface run-off. The run-off water was loaded with solid materials on its way down supplied by lateral and channel erosion. Figure 6 shows a channel with a slope gradient above $60^{\circ}$. The channel which developed in the avalanche de- posits reached a depth of $40-60 \mathrm{~m}$ and a width of $50-100 \mathrm{~m}$ (Fig. 6b). Figure $6 \mathrm{c}$ shows a widening of the channel erosion on several locations, caused by slope failures during the incision of the channel. When the debris flow happened, a check dam at the entrance of the catchment temporary blocked the material. The dam suddenly failed and increased 


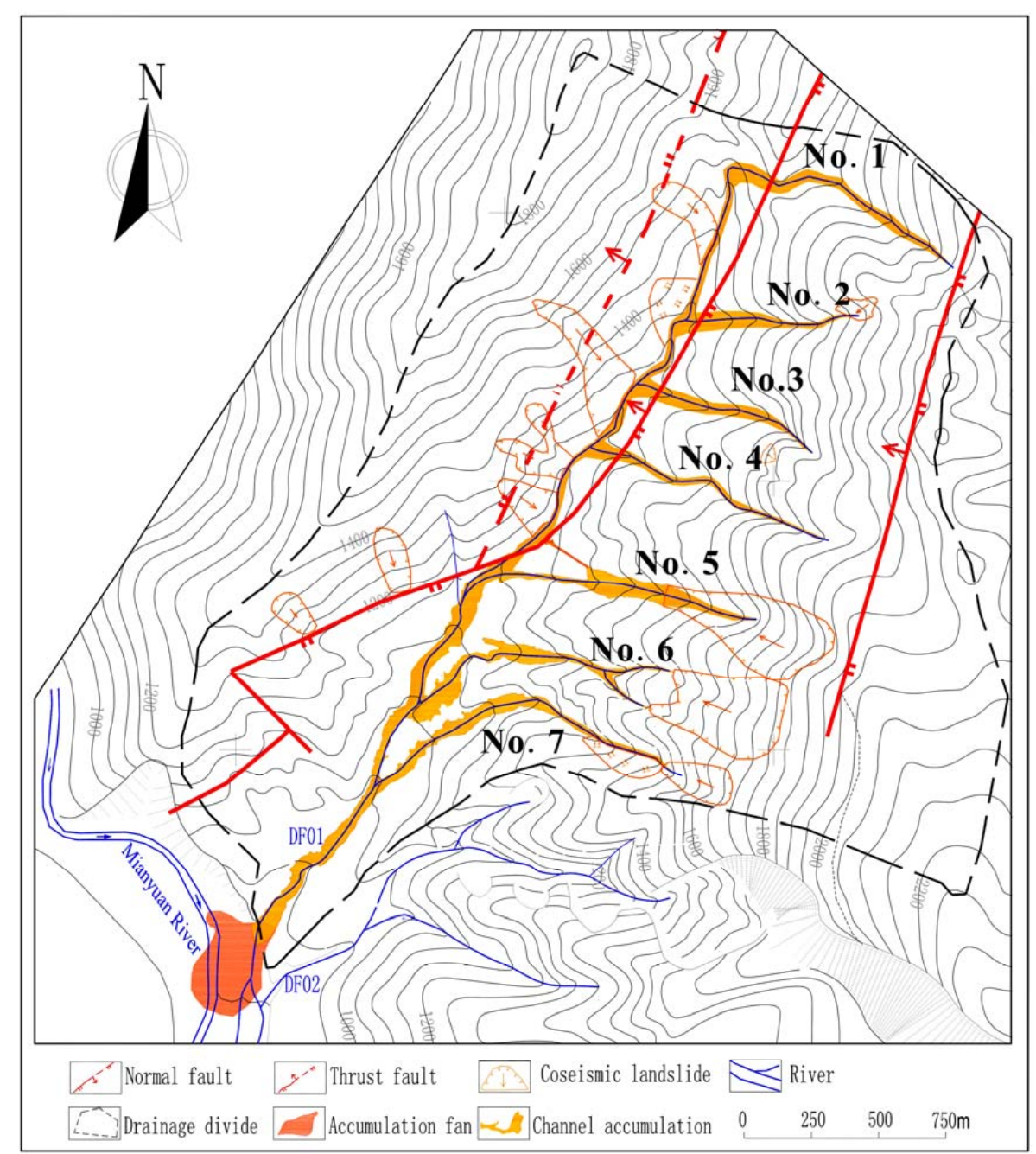

Fig. 7. Map of the 8.13 debris flow in the Zoumaling gully.

the devastating capacity of the debris flow which hit the Mianyuan River plane.

The Zoumaling catchment formed an ancient debris flow gully, which is composed of one main drainage channel and seven branches (Fig. 7). The channel gradient ranges from $8.5 \%$ to $36.1 \%$. The upstream terrain of the gully is very steep with a width of 5-15 m. In the middle and downstream part of the gully, the gradient is relatively gentle and the width is $40-60 \mathrm{~m}$. The loose deposits, triggered by the Wenchuan Earthquake, formed the main source for the debris flows in the catchment. The basic data of Zoumaling catchment is listed in Table 3. These seven branches played an important role in the supply of material for the debris flow. The debris source deposits in the 7 tributaries of the Zoumaling gully reached a total amount of $48.5 \times 10^{4} \mathrm{~m}^{3}$, surpassing the amount of material of the main gully, which is $35 \times 10^{4} \mathrm{~m}^{3}$. Figures 7 and 8 show that the loose deposits almost covered each branch in the catchment. Under severe rainstorm conditions, the deposits failed and transformed into debris flows. Compared to the tributaries, the slope gradient of the main gully is much smaller. During the rainstorm of 13 August 2010, debris flows were triggered first in each tributary. These then flowed into the main gully and consequently the deposits in main gully were reactivated, increasing the amount of debris flow material. A field survey revealed the destructive nature of the 8.13 debris flow with a volume of $83.5 \times 10^{4} \mathrm{~m}^{3}$ that occurred in the Zoumaling catchment (Fig. 9). The debris fan blocked the Mianyuan River with an outflow length of $300 \mathrm{~m}$ and a width of 50 $400 \mathrm{~m}$.

As shown in Fig. 10, the whole town of Qingping was covered by a massive amount of deposits, with an area extension of $140 \times 10^{4} \mathrm{~m}^{2}$. Figure 10a clearly shows the debris dam formed between the Zoumaling gully and the Wenjia gully. The distance between the two gullies is about $200 \mathrm{~m}$, and a barrier lake was formed in the gap between the two fans. A 


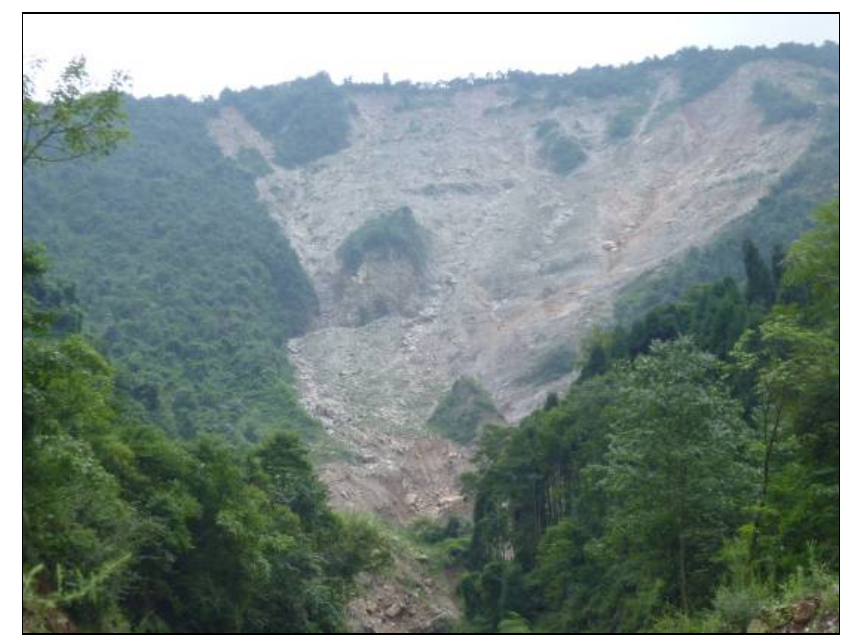

Fig. 8. Loose deposits in the upper part of the No. 5 branch of the Zoumaling gully.

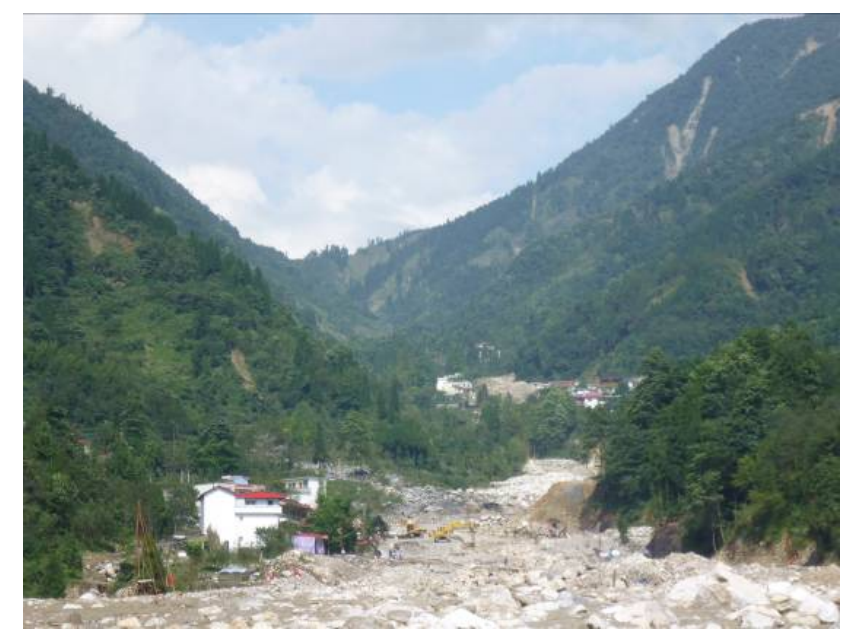

Fig. 9. An overview of the Zoumaling gully debris flow.

"rock-fill field" was formed with a length of about $4.3 \mathrm{~km}$, and a width between 400-500 $\mathrm{m}$ and an average thickness of $5 \mathrm{~m}$ (Fig. 10b and c). A great number of debris materials consisting of silt and rock blocks destroyed schools, gas stations, and 379 replacement housings. Seven people were killed, 7 people were missing and 33 people were injured. The other gullies mentioned in Table 1 were not involved in the 8.13 debris flow event due to the insufficient amount of source material stored in these valleys.

\subsection{Hongchun gully debris flow}

The Hongchun gully, located opposite the town of Yingxiu, has a catchment area of $5.35 \mathrm{~km}^{2}$. The highest part of the debris flow source area is at an elevation of $2168.4 \mathrm{~m}$. The height of the gully ranges from 880 to $1700 \mathrm{~m}$. The average gully gradient is $35.8 \%$ and the length of the main gully is about $3.6 \mathrm{~km}$. The Yingxiu-Beichuan fault passes through the gully. The upstream part of the catchment consists of three branches, which are called the Ganxipu, Dashuigou and Xindianzi gully respectively (Fig. 11). The terrain on both sides of the gully is very steep with an average slope gradient of $35^{\circ}$.

The Hongchun catchment forms an ancient debris flow gully. Before the Wenchuan Earthquake, around $200 \times 10^{4} \mathrm{~m}^{3}$ of loose deposits were distributed along both sides of the gully. A total of $150 \times 10^{4} \mathrm{~m}^{3}$ new loose deposits were formed during Wenchuan Earthquake. Six large landslides could be identified in the catchment by aerial photo interpretation (Fig. 11). These landslides blocked the drainage channel, increasing largely the risk of debris flow initiation.

A rainstorm occurred at 17:00 on 12 August, until 02:00 on 14 August 2010 in the Yingxiu Town region, which almost instantaneously triggered many hill-slope and channelized debris flows. Among them was the debris dam caused by the Hongchun gully debris flow, which changed the course of the river causing the flooding of the newly reconstructed Yingxiu town. Figure 12 shows the hourly and cumulative rainfall for this rain event. On 12 August 2010, $19.9 \mathrm{~mm}$ of rainfall was recorded between 17:00 and 24:00. A total of $126.8 \mathrm{~mm}$ rainfall was recorded during the entire day of 13 August. On 14 August, $23.4 \mathrm{~mm}$ was recorded between 0:00 and 02:00. A total cumulative rainfall of $162.1 \mathrm{~mm}$ in $33 \mathrm{~h}$ was recorded from 17:00 on 12 August until 02:00 on 14 August. Many eyewitnesses said that the most important debris flows started around 03:00, and ended at 04:30. Around $40 \times 10^{4} \mathrm{~m}^{3}$ debris material was deposited into Minjiang River plane, forming a $10 \mathrm{~m}$ high natural debris dam $100 \mathrm{~m}$ in length across the river, and $150 \mathrm{~m}$ in width along the river. After that, a flood destroyed the Yingxiu New Town. Figure 13 is an aerial photo taken on 15 August 2010, showing the debris dam and the inundated Yingxiu Town. The estimated maximum discharge of the river through the town was $570 \mathrm{~m}^{3} \mathrm{~s}^{-1}$ shortly after the debris flow occurrence and reached a value of $1400 \mathrm{~m}^{3} \mathrm{~s}^{-1}$ on 15 August (Tang et al., 2011). After an emergency dredge of the debris dam, the Yingxiu New Town finally recovered again to a safe area (Fig. 14).

\subsection{Longchi debris flow}

On 13 August 2010, the Longchi Town near Dujiangyan City was severely hit by debris flows. The triggering rainfall started around 13:30 and a $75 \mathrm{~mm} \mathrm{~h}^{-1}$ intensity rainfall was recorded from 16:00 to 17:00. From 16:00 until 18:00 the rainfall reached an amount of $128.3 \mathrm{~mm}$. Within $3 \mathrm{~h}$ the cumulative rainfall reached a total amount of $150 \mathrm{~mm}$. The debris flows occurred at 16:00.

The deposits of Longchi debris flow were mainly distributed along both sides of the Longxi River. During the field survey, 63 new landslides triggered by the heavy rainstorm on 13 August 2011 are detected (Fig. 15). The 

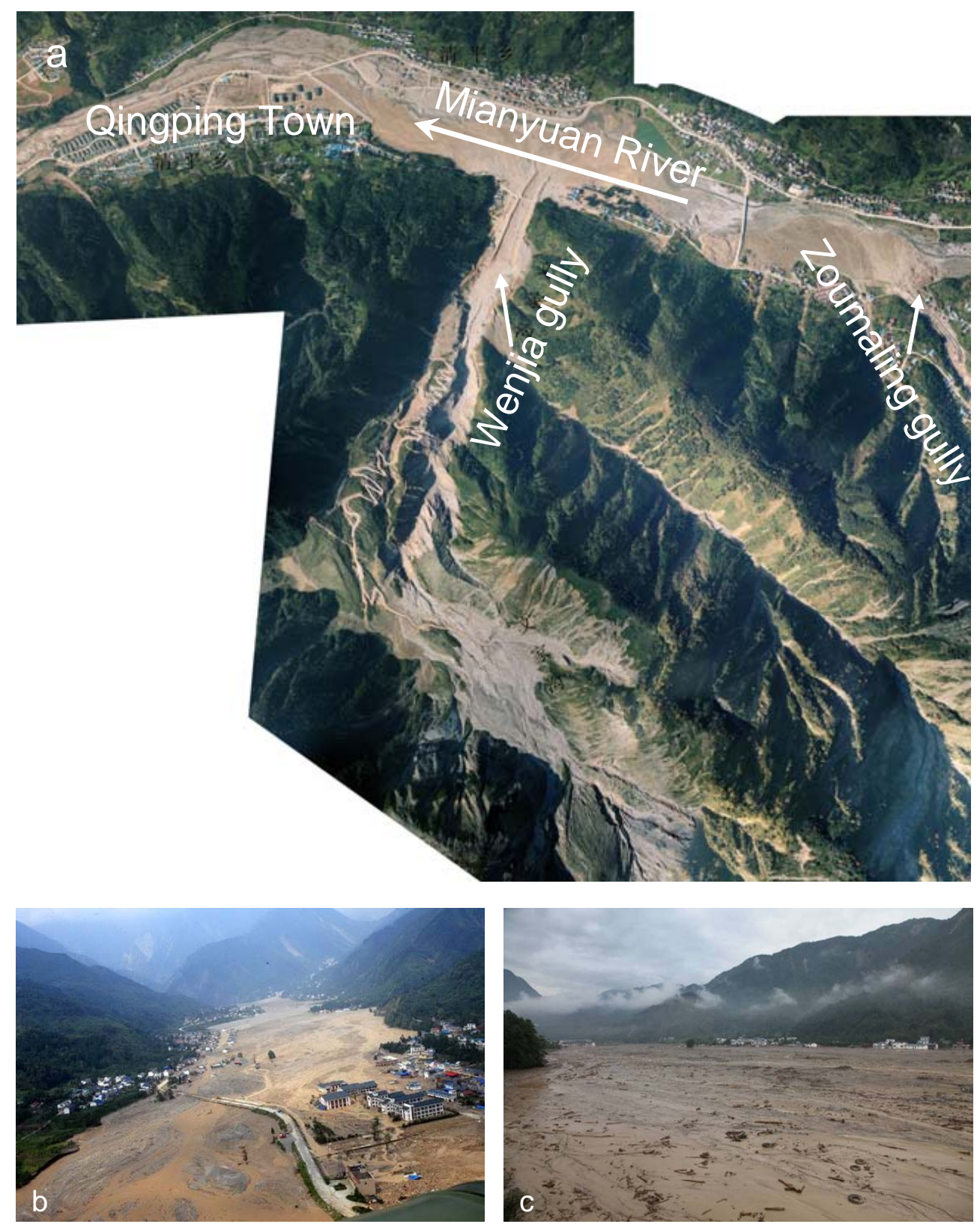

Fig. 10. Qingping Town buried by the 8.13 debris flows (a: aerial photograph taken after the 8.13 debris flows; b: photo of the buried Qingping Town taken from downstream to upstream of the Mianyuan River after the 8.13 debris flows; c: photo of the buried Qingping Town taken from upstream to downstream of the Mianyuan River after the 8.13 debris flows.)

landslides and debris flows were triggered simultaneously in 37 gullies and the total volume of debris material reached $778 \times 10^{4} \mathrm{~m}^{3}$. The riverbed increased $5-8 \mathrm{~m}$ in height. As shown in Fig. 16, the disaster destroyed and buried the original and reconstructed buildings along the Longxi River, causing heavy losses of lives and properties in Longchi Town.

\section{The characteristics of the 8.13 debris flows}

The common features of the 8.13 debris flows described above are their simultaneous occurrence, their unpredictability and destructiveness, their hazard chain effects, and the distribution along the earthquake fault. The source materials are mainly composed of the deposits of the earthquake induced landslides. An understanding of the characteristics of these debris flows is useful for the development of guidelines for the prevention of debris flows in the earthquake zone. 


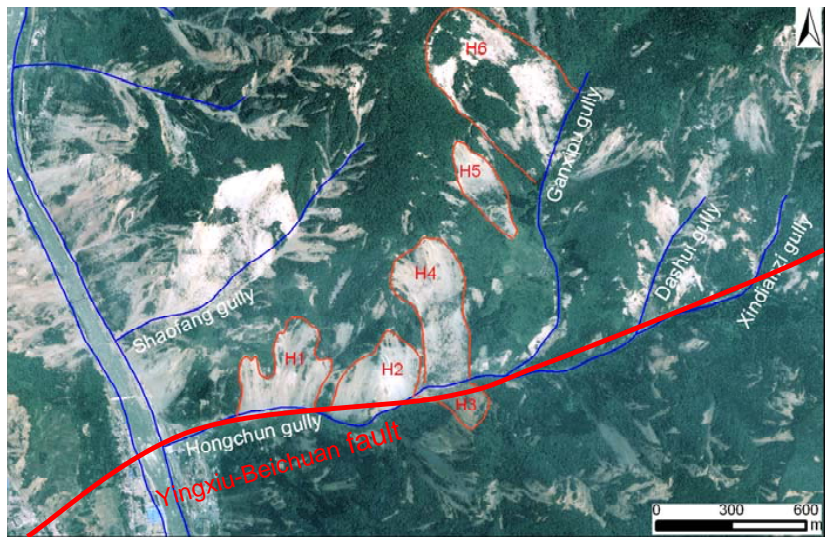

Fig. 11. Loose deposits induced by the 2008 Wenchuan Earthquake in the Hongchun gully, with an increase of loose material of about $150 \times 10^{4} \mathrm{~m}^{3} . \mathrm{H}$ is the abbreviations of landslides.

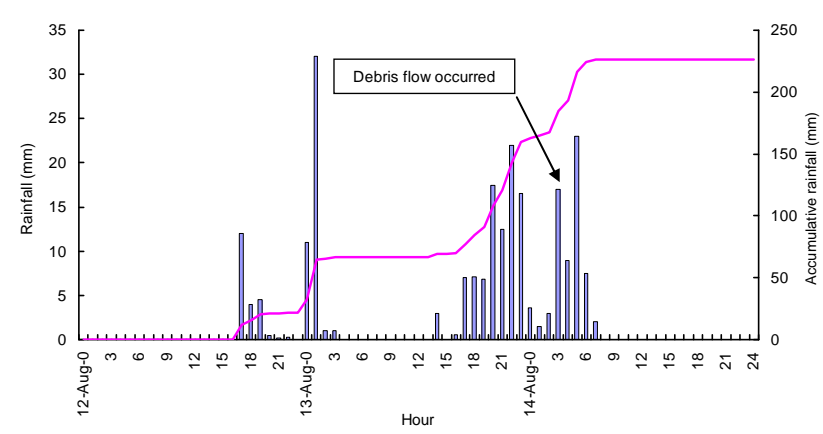

Fig. 12. Distribution of hourly and cumulative precipitation between 12 and 14 August 2010 in Yingxiu Town.

\subsection{Simultaneous occurrence}

Huang (2010) estimated that the volume of loose materials triggered during the 2008 Wenchuan Earthquake may have amounted to $10^{9} \mathrm{~m}^{3}$. Within the earthquake zone, three kinds of loose material could be distinguished as a source for debris flows: large-scale deposits, surface loose deposits, and channel deposits. Large-scale deposits mainly originate from huge rock slides and rock avalanches triggered by the Wenchuan Earthquake, which accumulated in flat areas, at the toe of slopes, and in large channels. This kind of deposits is the main source material for the Wenjia gully debris flow. The channel deposits are formed due to relative smaller failures on hill slopes. The deposits can block the drainage system and can result in severe consequences. The outbreak of the Hongchun gully debris flow is closely related to this kind of channel deposits. The shallow debris deposits found on steep slopes were triggered during the Wenchuan Earthquake, which is considered as the potential source of debris flows. The above mentioned three material sources were all triggered by the Wechuan Earthquake. Together with the original loose solids sources, the debris material became very

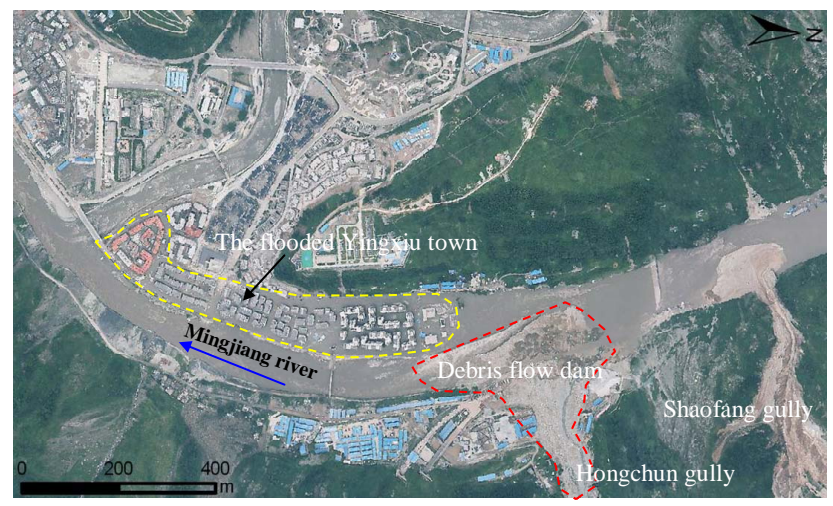

Fig. 13. Aerial photograph of the Hongchun gully debris flow and related flood (Supplied by the Sichuan geological environmental monitoring station).



Fig. 14. Drainage works for the debris dam in Yingxiu Town after the 8.13 Hongchun gully debris flows.

abundant. Under rainfall condition, the debris flows can be triggered in every gully, showing the simultaneous character of these processes (Fig. 17).

\subsection{Unpredictability}

The occurrence of debris flow in the earthquake region is unpredictable, which can be illustrated by the following two points.

(1) The rainfall duration that triggered the debris flows was remarkably shorter after the Wenchuan Earthquake. The rainfall in Qingping Town started at 22:30 on 12 August, while the debris flow occurred at 00:40 on 13 August, only after a period of two hours. In the Hongchun gully, a heavy rainstorm began at 20:00 on 13 August and the massive debris flow broke out on 14 August at 01:20. The same situation appeared in Longchi Town: a heavy rain started at 15:30 on 13 August and a debris flow occurred at 16:00 on the same day. (2) The rainfall threshold of the debris flows was greatly reduced. Similar to the Chi-Chi Earthquake in Taiwan, the post-seismic initiating rainfall intensity and 
Table 4. A comparison between observed and calculated volumes of solid material of debris flows in the Wenjia catchment.

\begin{tabular}{llllll}
\hline Code & Date & $\begin{array}{l}\text { Rainfall } \\
\text { frequency P }\end{array}$ & $\begin{array}{l}\text { Calculated } \\
Q_{\mathrm{H}}\left(\times 10^{4} \mathrm{~m}^{3}\right)\end{array}$ & $\begin{array}{l}\text { Observed } Q_{\mathrm{H} 1} \\
\left(\times 10^{4} \mathrm{~m}^{3}\right)\end{array}$ & $Q_{\mathrm{H} 1 / Q_{\mathrm{H}}}$ \\
\hline 1 & 24 Sep. 2008. & $20 \%$ & 13.90 & 90 & 6.5 \\
\hline 2 & 31. Jul. 2010 & $20 \%$ & 13.90 & 30 & 2.2 \\
\hline 3 & 13 Aug. 2010 & $2 \%$ & 37.4 & 450 & 12.0 \\
\hline 4 & 19 Aug. 2010. & $10 \%$ & 20.81 & 30 & 1.4 \\
\hline 5 & 18 Sep. 2010. & $20 \%$ & 13.90 & 17.6 & 1.3 \\
\hline
\end{tabular}

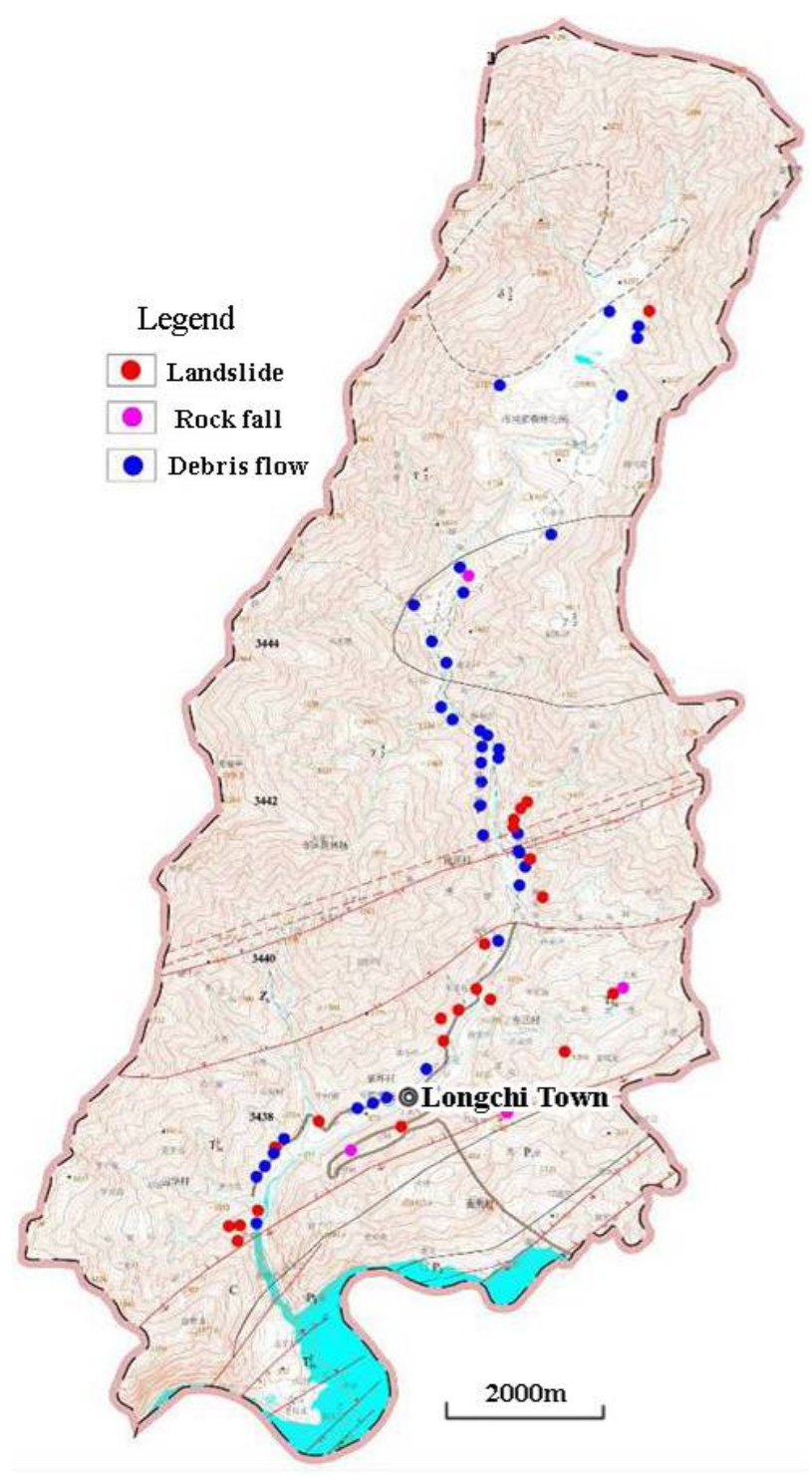

Fig. 15. The new geo-hazards triggered by the rainstorm on $13 \mathrm{Au}-$ gust 2010 along the Longxi River.
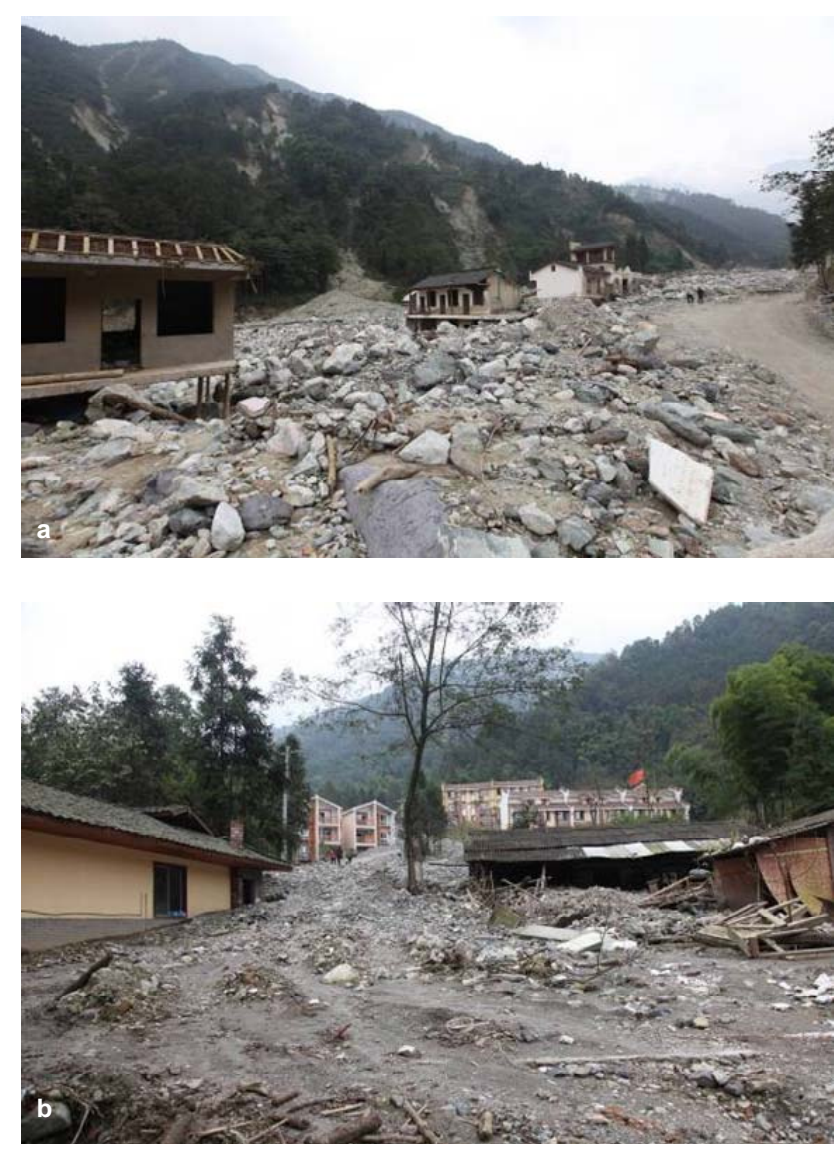

Fig. 16. Residential housing destroyed by the 8.13 Longchi debris flow in the Longxi catchment ((a): the housing located along the Longxi river destroyed by the debris flow; (b): the housing located on the right side of Longxi river was destroyed by the debris flow). 


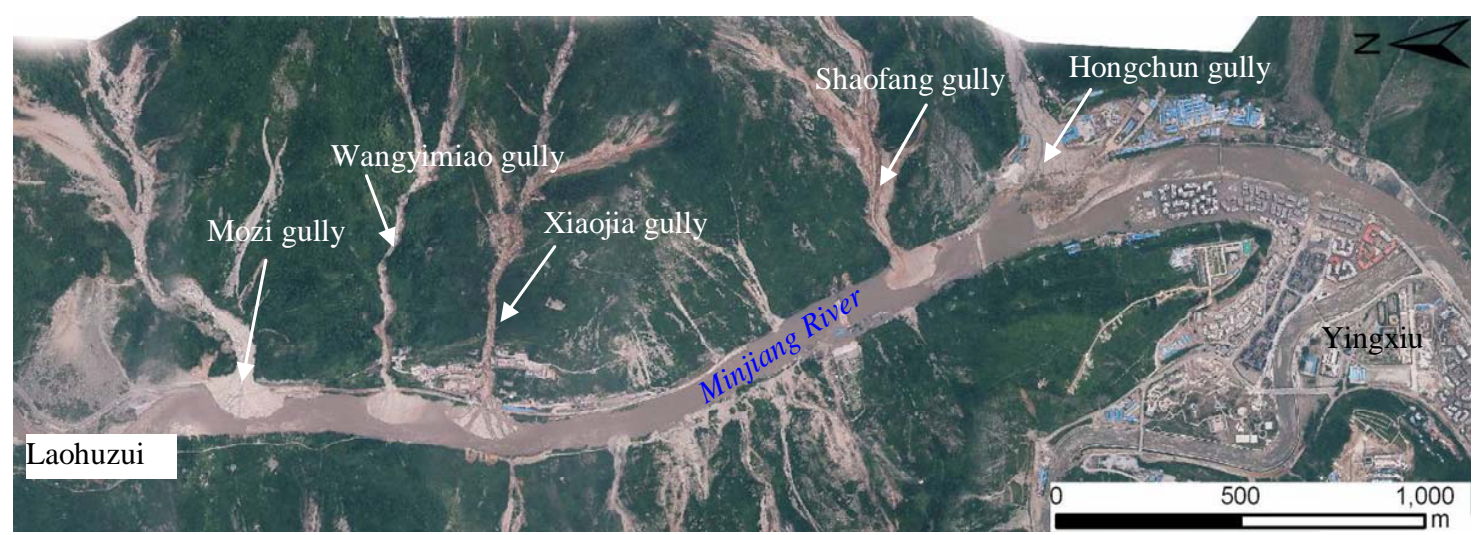

Fig. 17. Aerial photograph of the 8.13 debris flows between Yingxiu Town and Laohuzui along the Minjiang River (provided by the Sichuan geological environmental monitoring station).



Fig. 18. Check dam destroyed by the 8.13 debris flow near the outlet of the Wenjia gully.

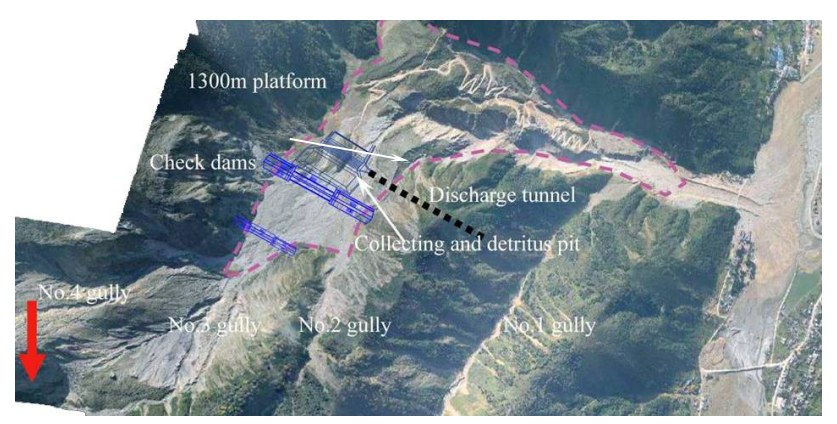

Fig. 19. An overview of the Wenjia gully debris flow and the remedial works.

accumulative rainfall for debris flows' appeared to be onethird lower compared to the pre-seismic rainfall thresholds. Tang and Liang (2008), studying the Beichuan debris flows of 24 September 2008 , concluded that the early cumulative rainfall threshold for debris flows in the Beichuan Country was reduced by approximately $14.8 \%-22.1 \%$, while the hourly rainfall intensity was reduced by $25.4 \%-31.6 \%$. Cui

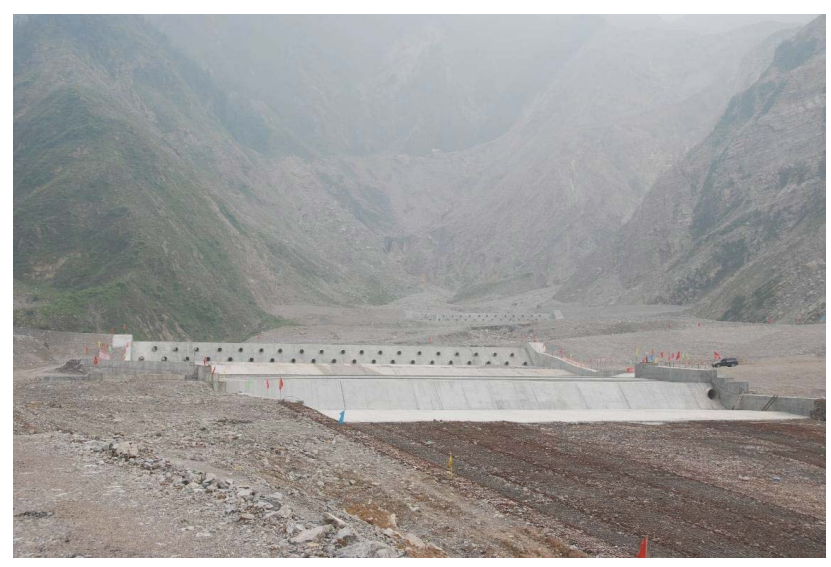

Fig. 20. Drainage system constructed in the upstream part of the Wenjia gully.

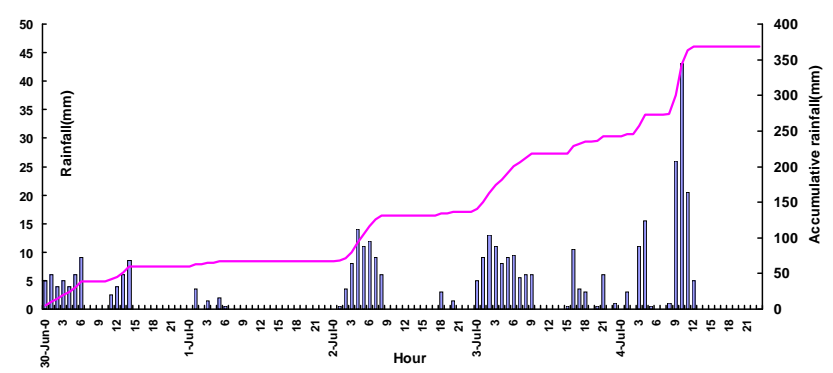

Fig. 21. Distribution of hourly and cumulative precipitation between 30 June and 4 July 2010 in Qingping Town.

et al. (2010) found that the post-seismic critical hourly rainfall of the Beichuan debris flows recorded by rainfall observation stations was only $37.4 \mathrm{~mm}$. Both the variability in rainfall duration and threshold for debris flow after the earthquake contributed to the unpredictability of debris flow. 


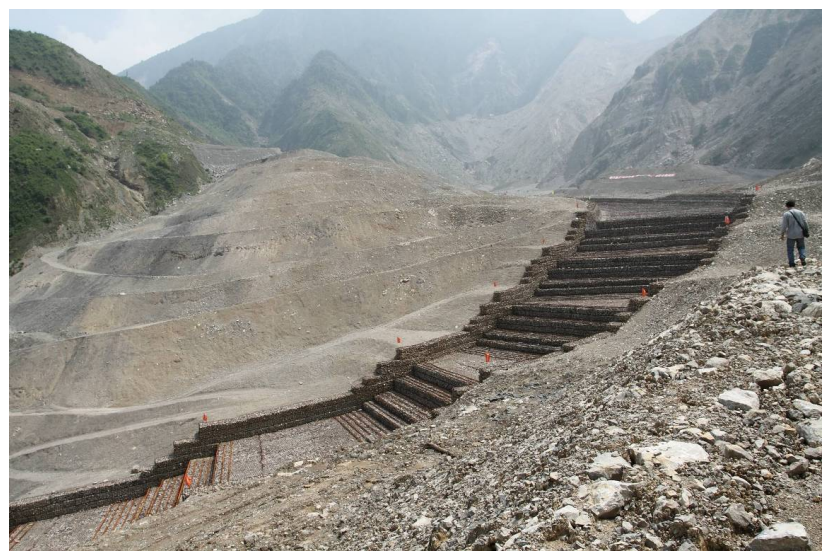

Fig. 22. A flexible erosion prevention system constructed in the Wenjia gully.

\subsection{Destructive character}

The devastating debris flows which happened after the Wenchuan Earthquake destroyed a number of protective constructions (Fig. 18) were caused by three factors: (1) High speed. The terrains of the Wenchuan Earthquake area are very steep with high channel gradients, generating high flow velocities. (2) Large magnitude. Due to the presence of abundant source materials, large magnitudes of debris flow material are always triggered with consequently extensive deposition areas, for instance, the spreading areas of the Wenjia gully and the Zoumaling gully debris flows. (3) Intermittent character. Due to the blocking effect of slope material in the channels, the debris flow events show paroxysmal and intermittent features.

\subsection{Chain effect of the disaster}

In our study we showed that debris flows triggered by rainfall can form dams, which can block the river and cause the flooding of buildings and infrastructures for transport. That was the main cause of the loss of property and lives in the Qingping and Yingxiu areas. Several conditions for debris flowing may cause secondary disasters: (1) The direction of debris flow gullies should be more or less perpendicular to the direction of the main river. (2) Large amounts of source material must be available to block the river. (3) The debris flows should have an intermittent character.

\subsection{Distribution along faults}

Firstly, as shown in Fig. 1, the outbreak points of debris flows are mainly distributed along a seismic active fault, i.e. the Yingxiu-Beichuan fault. The gullies, caused by debris flows, are closely related to these earthquake faults. For example, the central fault crosses the Hongchun and Zoumaling catchment (Fig. 11). The Wenjia gully is just located at the cross- ing and scattered part of the Yingxiu-Beichuan fault near the stress concentration zone (Xu, 2011). The debris flows in Longchi Town are also well developed within a certain range of seismogenic faults (Fig. 15). Secondly, the debris flow occurred in a seismic zone with the intensity above IX.

\subsection{Channel erosion}

In the Wenchuan Earthquake region, the unconsolidated and uncemented material source is extraordinarily rich in the gully. So it is difficult to move forward overall with the effect of runoff. In the process of channel erosion, the slopes continuously collapse by lateral erosion. Deep erosive channels gradually developed along the main stream of the catchment. Such phenomena was found in the Wenjia gully. This channelized type of erosion is a new feature of debris flow development in the earthquake zone.

\section{Discussion about debris flow prevention in the earthquake zone}

\subsection{Prevention measures before the 8.13 debris flows}

Before the 8.13 debris flows, the conventional design specifications were used. However our knowledge and design codes appeared to be insufficient for the debris flows occurred after the earthquake. The mitigating constructions in the Wenjia catchment were completed before the 8.13 debris flows. The major mitigation measures consisted of 19 check dams along the gully, with a height of $3 \mathrm{~m}-6 \mathrm{~m}$. They had a top width of $1.5 \mathrm{~m}$, and a bottom width of $4.45 \mathrm{~m}-6.4 \mathrm{~m}$ with an embedment depth of only $2 \mathrm{~m}$. These check dams proved to be useless during the 8.13 debris flow disasters. Moreover, failure of the last dam at the exit of gully, with a length of $84 \mathrm{~m}$ and $6 \mathrm{~m}$ in height, enlarged the damage of the Qingping Town. Eyewitnesses described how the debris gathered behind the last dam, increasing finally the impact of the amount of material after the failure of dam. The hyper-concentrated flow formed a huge wave, destroying instantly the housing and infrastructures, such as roads and bridges. Figure 17 shows the situation after the destruction of the dam. The major mitigation measure in Hongchun gully was a stone check dam at the toe of No. $\mathrm{H}_{2}$ landslide (Fig. 11), with a height of $6.5 \mathrm{~m}$ and a length of $70 \mathrm{~m}$. The work was not carried out yet when the 8.13 events happened. However, the design proved to be useless since the movement and discharge of the 8.13 debris flow is larger than the calculated values used for the design of the dam. The calculated volume of solid materials was $1.92 \times 10^{4} \mathrm{~m}^{3}$ based on a return period of $50 \mathrm{yr}$. While, the actual debris discharge during the 8.13 events was $70 \times 10^{4} \mathrm{~m}^{3}$, which is 36.5 times larger than the calculated value. 


\subsection{Prevention measures after the 8.13 debris flow}

The 8.13 catastrophic debris flows remind us that these debris flows are significantly different in distribution, initiation and their consequences from those developed before the earthquake or in non-seismic areas. The conventional vision and experience to control the debris flow hazard in areas suffering strong earthquakes are not suitable any more. We have the following suggestions for prevention works of debris flows, which are especially suitable for the Wenchuan Earthquake region.

\subsubsection{Improve the design standard}

According to The specification of Geological Investigations of Debris Flow Stabilization in China (2006), the debris flow discharge can be calculated by Eq. (1):

$Q_{c}=(1+\phi) \cdot Q_{p} \cdot D_{c}$

where $Q_{c}\left(\mathrm{~m}^{3} / \mathrm{s}\right)$ is the peak discharge of a debris flow; $Q_{p}\left(\mathrm{~m}^{3} \mathrm{~s}^{-1}\right)$ is the peak discharge of rainfall with rainfall frequency $\mathrm{P} ; \phi$ is the debris flow correction factor, $\phi=$ $\left(\gamma_{c}-\gamma_{w}\right) /\left(\gamma_{h}-\gamma_{c}\right) ; D_{c}$ is the obstructive coefficient of debris flowwhich ranges from 1.5 to $2.5 ; \gamma_{c}$ is the total unit weight of debris flow material $\left(\mathrm{kN} \mathrm{m}^{-3}\right) ; \gamma_{w}$ is unit weight of water $\left(10 \mathrm{kN} \mathrm{m}^{-3}\right) ; \gamma_{h}$ is the unit weight of solid material $\left(\mathrm{kN} \mathrm{m}^{-3}\right)$;

The total volume of a certain debris flow event can be calculated by Eq. (2):

$Q=0.264 \cdot T \cdot Q_{c}$

where $T$ is the duration of the debris flow (s).

The total solid volume of a certain debris flow event can be calculated by Eq. (3):

$Q_{H}=Q\left(\gamma_{c}-\gamma_{w}\right) /\left(\gamma_{h}-\gamma_{w}\right)$

Using Eqs. (1)-(3), calculated discharges and volumes seem to be underestimated for the post seismic debris flows with huge amounts of source materials. For example, the calculated $Q_{c}$ value of the Hongchun gully before the 8.13 debris flows occurred, was $131.57 \mathrm{~m}^{3} \mathrm{~s}^{-1}$ with a rainfall frequency of $2 \%$. In 1962, an extreme rainstorm event with 50 min. duration occurred. The duration of the debris flow was assumed to be equal to $3000 \mathrm{~s}$. The total discharge of debris flow material $Q$ is around $4.46 \times 10^{4} \mathrm{~m}^{3}$, using Eq. (2). According to Eq. (3), the calculated total volume of solid materials $Q_{H}$ is $1.92 \times 10^{4} \mathrm{~m}^{3}$. In reality, the total volume of solid materials $Q_{H}$ of the Hongchun gully debris flow event reached a value of $70 \times 10^{4} \mathrm{~m}^{3}$, which is 36.5 times larger than the calculated result. Therefore, if the control project had been completed before the 13 August 2010 event, it still would have been still impossible to prevent this debris flow disaster.

The value of observed and calculated $Q_{H}$ 's for five typical debris flows occurring in the Wenjia catchment are listed in Table 4, by assuming a duration of $3600 \mathrm{~s}$. In the No. 1, 2 and
4 events, the observed volumes of debris flow solid materials decrease and are close to the calculated values when subjected to the same rainfall frequency of $20 \%$. The observed volumes of solid materials of debris flows can be up to 10 times larger than the calculated volumes. Hence, it is risky to design the mitigation measures for such kind of debris flows according to present debris flow stabilization specification.

\subsubsection{Update the design philosophy}

Debris flows are mixtures of loose solids and water. For an outbreak of debris flows, both sufficient source materials and suitable amounts of water are indispensable. The Wenchuan Earthquake supplied an extreme amount of source materials in the region where extreme rainfall occurred frequently. Therefore, to prevent the generation of debris flows, water and the solid source materials should be controlled.

1. Control water supply. When the water source is sufficient at the part of headstream or upper valley, the drainage measures, such as drainage tunnels and surface-cut drains, should be used to cut or remove surface water. This method minimizes the amount of surface water flowing into the gully and mitigates or even eliminates the triggering conditions of debris flows. For example, the Wenjia gully has about $3000 \times 10^{4} \mathrm{~m}^{3}$ source material accumulated in the lower part of the catchment on the " $1300 \mathrm{~m}$ platform". This material can easily be transformed into debris flows by channelized water erosion. Considering the special terrain in the Wenjia catchment, after the 8.13 debris flow, a one diversion tunnel was constructed near the " $1300 \mathrm{~m}$ platform", which leads a diversion of the upstream surface water into the No. 1 branch as shown in Fig. 19. The length of the diversion tunnel is $450 \mathrm{~m}$, the inner crosssection is $4.5 \times 3.5 \mathrm{~m}^{2}$ and the gradient is $5 \%$. In order to improve the diversion capacity, two check dams with $5 \mathrm{~m}$ height and one sand trap were built upstream of the diversion tunnel entrance (Figs. 19 and 20). The main role of the dams is to prevent the deposits coming from the upstream branches (No.2-No.4) from block the diversion tunnel. The surface water coming from upstream can be diverted into the No. 1 branch by filtering in the sand trap. During the rainy season from June to August, 2011, several rainstorms with rainfall intensities similar to the 8.13 events attacked the Qingping Town again, and the mitigation measures which were completed in May 2011 proved to be effective in the Wenjia gully. Figure 21 shows a cumulative rainfall of $368.5 \mathrm{~mm}$ in the Wenjia gully region from 30 June to 4 July 2011. On 4 July, the rainfall intensity was $43 \mathrm{~mm} \mathrm{~h}^{-1}$ with a duration of $10 \mathrm{~h}$. The floods and debris flow, which developed in the upstream part of the catchment was diverted successfully through the tunnel. From 14 to 21 August 2011, the cumulative rainfall reached an amount of $404.5 \mathrm{~mm}$, and the flood was 
again successfully discharged to the diversion tunnel, which proved the effectiveness of the control measures separating the sand and water.

2. Measures to mitigate the rock falls and landslides should be improved. Retaining walls, drainage systems and other preventative measures should be adopted along the channel to prevent the supply of source materials by rock falls and landslides for debris flows.

3. Control of the channelized erosion by using flexible drainage channels. Considering the channel erosion characteristics of the debris flows occurring after the Wenchuan Earthquake, drainage channels with consistent flexible reinforced stone cages are used to mitigate the concentrated erosion. During the debris flow process, some local failures of the drainage system may lead to infiltration of water into the loose deposits. A new runoff erosion channel can be formed and continually expanded, which could result in a failure of the drainage system. Compared to the traditional reinforced concrete drainage systems, the reinforced flexible stone cages could self-repair the damaged parts. Moreover, it is easy to repair the local failures and replace the stone cages. After the 8.13 debris flows, flexible drainage systems were constructed in the channelized midstream part of the Wenjia gully (Fig. 22) and the downstream part of the Hongchun gully. This type of mitigation method also proved to be effective during the debris flow events which happened during the 2011 rainy season.

\subsubsection{Attaching great importance to the disaster chain effects of debris flows}

Secondary disasters triggered by debris flows greatly affected the reconstruction work which brings us to the following recommendations: (1) Re-investigation and assessment of the large-scale debris flow hazards in the disaster areas. Based on the experience of the failure of prevention measures due to the 8.13 catastrophic debris flows and with the assistance of remote sensing interpretation and field surveys, the new loose material distributed in the gullies should be investigated in the earthquake region; (2) Monitoring of the river evolution in the disaster areas. Observation points along the major rivers should be established to monitor the flow rate and sediment transport. Sediment budget analyses for major river catchments must be carried out to analyze the evolution of the height of the river planes, which are necessary to guide the reconstruction work in the earthquake area; (3) Further safety assessments should be carried out of reconstruction projects, including housing, roads and other reconstruction projects located in the lower parts along the river and near the exits of debris flow gullies in the earthquake region; (4) An investigation of the impact of the uplift of riverbeds for the evaluation of reconstruction plans for buildings and infrastructures. According to the prediction of the uplift of the main rivers in the next few years, the responsible departments should modify the reconstruction planning to guarantee a sustainable, long-term development.

\section{Conclusions}

The 8.13 debris flows showed the following main features: (1) The catastrophic debris flows of the Wenjia gully, Zoumaling gully, Hongchun gully, and Longchi occurred in the same period from 12 to 14 August 2011 in the earthquake zone and destroyed local urban housing and infrastructure. (2) The common features of the 8.13 debris flows are that they occur simultaneously, with unpredictability and large destructive power. The 8.13 debris flows are mainly distributed along the earthquake fault zone, in which abundant loose source material deposits were supplied during the 2008 Wenchuan Earthquake. A huge amount of loose debris flow source material, up to $5000 \times 10^{4} \mathrm{~m}^{3}$, was deposited during the earthquake along the Wenjia gully. These loose deposits could be easily remobilised by channel erosion under intensive rainfall, generating large and devastating debris flows. These catastrophic processes have increased the number of mitigation works for the debris flow in the earthquake region. (3) The actual discharge of the 8.13 debris flows is much larger (until 10 times) than the values calculated according to the current codes. It is therefore necessary to improve the design standards for debris flow mitigation in earthquake zones. (4) New mitigation measures for debris flow mitigation proved to be effective during the intensive rainy season in 2011. After the 8.13 events, check dams, in combination with a sediment trap and a diversion tunnel constructed in the upstream part of Wenjia gully successfully separated and diverted the water and solid materials and prevented the occurrence of new catastrophic debris flows. Also, the constructing of a flexible drainage system with reinforced stone cages successfully prevented the lateral erosion along the erosion channels of the source materials for potential debris flows.

Acknowledgements. This research is financially supported by the National Basic Research Program "973", Project of the Ministry of Science and Technology of the Peoples Republic of China (2008CB425801), the Creative Team Program of the Ministry of Education in China (IRT0812), as well as the open fund on research on large-scale landslides triggered by the Wenchuan Earthquake provided by the State Key Laboratory of Geo-environment Protection and Geo-hazard Prevention. The comments and suggestions from reviwers and editors, which have made the presentation more clear, the analysis more closed to advancements worldwide are appreciated .

Edited by: F. Luino

Reviewed by: L. Franzi and another anonymous referee 


\section{References}

Ashida, K., Egashira, S., and Ohtsuki, H.: Dynamic behavior of soil mass produced by slope failure, Annuals, DPRI, 26B-2, 315327, 1983 (in Japanese).

Berti, M. and Simoni, A.: Debris flow initiation in a highly conductive soil, in: Proceedings of International Conference on Fast Slope Movements-Prediction and Prevention for Risk Mitigation, ICFSM2003, Naples, 11-13 May 2003, 29-36, 2003.

Berti, M., Genevois, R., Simoni, A. M., and Tecca, P. R.: Field observations of a debris flow event in the dolomites, Geomorphology, 29, 265-274, 1999.

China's ministry of land and resources: Specification of geological investigation for debris flow stabilization, 2006 (in Chinese).

Campell, R. H.: Soil slips, debris flows and rainstorms in the Santa Monica mountains and vicinity, Geological Survey Professional Paper, 851, Southern California, U.S., 51, 1975.

Cui, P., Wei, F. Q., He, S. M., and You, Y.: Mountain disasters induced by the Earthquake of May 12 in Wenchuan and the disasters mitigation, J. Mt. Sci., 26, 280-282, 2010 (in Chinese).

Fryxell, F. M. and Horberg, L.: Alpine mudflows in Grand Teton National Park, Wyoming, Geol. Soc. Am. Bull., 54, 457-472, 1943.

Gregoretti, G. and Fontana, G. D.: The triggering of debris flow due to channel-bed failure in some alpine headwater catchments of the Dolomites: analyses of critical runoff, Hydrol. Process., 22, 2248-2263, 2008.

Huang, R. Q.: After effect of geohazards induced by the Wenchuan Earthquake, Journal of Engineering Geology, 19, 145-151, 2010 (in Chinese).

Huang, R.Q. and Li, W. L.: Fault effect analysis of geo-hazard triggered by Wenchuan Earthquake, J. Eng. Geol., 17, 19-28, 2009 (in Chinese).
Huang, H. Q. and Zhao, Q. H.: Basic characteristics and preliminary mechanism analysis of large scale rock slide-sturzstrom at Wenjia gully triggered by Wenchuan Earthquake, J. Eng. Geol., 18, 168-177, 2010 (in Chinese).

Iverson, R. M.: The physics of debris flows, Rev. Geohys, 35, 245 296, 1997.

Iverson, R. M., Reid, M. E., and LaHusen, R. G.: Debris flow mobilization from landslides, Annu Rev. Earth Pl. Sc., 25, 85-138, 1997.

Johnson, A. M., Rodine, J. R.: Debris Flow, in: Slope Instability, edited by: Brundsden, D. and Prior, D. B., John Wiley \& Sons, 257-361, 1984.

Sassa, K., Takei, A., and Kobashi, S.: Landslides triggered by vertical subsidence, Proc. International Symposium on Landslides, New Delhi, 1, 49-54, 1980.

Shieh, C. L., Chen, Y. S., Tsai, Y. J., and Wu, J. H.: Variability in rainfall threshold for debris flow after the Chi-Chi earthquake in central Taiwan, China, Int. J. Sediment Res., 23, 177-188, 2009.

Tang, C. and Liang, J. T.: Characteristics of debris flows in Beichuan epicenter of the Wenchuan Earthquake triggered by rain storm on September 24, 2008, J. Eng. Geol., 16, 751-758, 2008 (in Chinese)

Tang, C., Zhu, J., Ding, J., Cui, X. F., Chen, L., and Zhang, J. S.: Catastrophic debris flows triggered by a 14 August 2010 rainfall at the epicentre of the Wenchuan earthquake, Landslides, 2011.

Tani, I.: On debris flow (Yamatsunami), Water Science, 60, 106126, 1968 (in Japanese).

Takahashi, T.: Debris flow, Balkema, Rotterdam, 165, 1991.

Xie, H., Zhong, D. L., Jiao, Z., and Zhang, J. S.: Debris Flow in Wenchuan Quake hit Area in 2008, Journal of Mountain Science, 27, 501-509, 2009 (in Chinese).

Xu, Q., Zhang, S., and Li, W. L.: Spatial Distribution of Largescale Landslides Induced by the 5.12 Wenchuan Earthquake, J. Mt. Sci., 8, 246-260, 2011. 